\title{
Pengaruh Lingkungan Fisik, Promosi dan Harga Terhadap Keputusan Wali Murid Dalam Menentukan Pendidikan Anak di SMK Cendikia Bangsa
}

\author{
Ahyani ${ }^{1}$, Siti Nurhasanah ${ }^{2}$ \\ Universitas Pamulang, Email : dosen02444@unpam.ac.id
}

\begin{abstract}
Abstrak. Penelitian ini untuk mengetahui dan menganalisis pengaruh Lingkungan Fisik, Promosi dan Harga Terhadap Keputusan Wali Murid Dalam Menentukan Pendidikan Anak Di SMK Cendikia Bangsa. Penelitian menggunakan metode Asosiatif. Sampel yang digunakan sebanyak 175 responden. Analisi data menggunakan regresi linier sederhana, regresi linier berganda, koefisien determinasi, uji thitung dan uji Fhitung. Hasil penelitian sebagai berikut: 1). Secara parsial lingkungan fisik berpengaruh positif dan signifikan terhadap keputusan wali murid dalam menentukan pendidikan anak di SMK Cendikia Bangsa. 2). Secara parsial promosi berpengaruh positif dan signifikan terhadap keputusan wali murid dalam menentukan pendidikan anak di SMK Cendikia Bangsa. 3).Secara parsial harga berpengaruh negatif dan signifikan terhadap keputusan wali murid dalam menentukan pendidikan anak di SMK Cendikia Bangsa. 4). Secara simultan lingkungan fisik, promosi dan harga berpengaruh positif dan signifikan terhadap keputusan wali murid dalam menentukan pendidikan anak di SMK Cendikia Bangsa.
\end{abstract}

Kata Kunci: Lingkungan Fisik, Promosi, Harga, dan Keputusan Wali Murid.

Abstract. The purpose of this study was to determine and analyze the influence of the Physical Environment, Promotion and Pricing Against the Decisions of the Student Guardian in Determining Children's Education at SMK Cendikia Bangsa. Research using the Associative method. The sample used was 175 respondents. Data analysis techniques using simple linear regression, multiple linear regression, coefficient of determination, $t$-test and F-test. The results of the study are as follows: 1 ). Partially the physical environment has a positive and significant influence on the decisions of guardians of students in determining children's education at SMK Cendikia Bangsa. 2). Partially, promotion has a positive and significant influence on the decision of guardians of students in determining children's education at SMK Cendikia Bangsa. 3). Partially, the price has a negative and significant effect on the decision of guardians of students in determining children's education at SMK Cendikia Bangsa. 4). Simultaneously the physical environment, promotions and prices have a positive and significant effect on the decisions of guardians of students in determining children's education at SMK Cendikia Bangsa.

Keywords: Physical Environment, Promotion, Price, Location and Purchasing Decisions. 


\section{A. PENDAHULUAN}

SMK Cendikia Bangsa merupakan salah satu sekolah swasta yang berlokasi di Kecamatan Legok kabupaten Tangerang. Dengan bersekolah di SMK Cendikia Bangsa, diharapkan bisa meningkatkan kemampuan generasi penerus bangsa yang pandai dan memiliki ahlak yang mulia. Berdasarkan data empiris yang penulis peroleh darisekolah ini diketahui bahwa permasalahan yang dihadapi oleh SMK Cendikia Bangsa adalah terjadinya penurunan jumlah siswa.

Tabel 1 Jumlah Siswa SMK Cendikia Bangsa Legok Tangerang

\begin{tabular}{|c|c|c|c|c|}
\hline Tahun & $\begin{array}{c}\text { Jumlah Siswa } \\
\text { Awal Tahun }\end{array}$ & $\begin{array}{c}\text { Jumlah Siswa } \\
\text { Masuk/Baru }\end{array}$ & $\begin{array}{c}\text { Jumlah Siswa } \\
\text { Akhir Tahun }\end{array}$ & $\%$ \\
\hline $2016 / 2017$ & 150 & 50 & 200 & $33,3 \%$ \\
\hline $2017 / 2018$ & 200 & 65 & 265 & $32,5 \%$ \\
\hline $2018 / 2019$ & 265 & 45 & 310 & $17,0 \%$ \\
\hline
\end{tabular}

Sumber : SMK Cendikia Bangsa (2020)

Tabel 1 diketahui bahwa jumlah siswa baru yang masuk pada SMK Cendikia Bangsa mengalami fluktuatif namun cenderung menurun. Pada tahun ajaran 2016/2017 jumlah siswa baru sebanyak 50 siswa kemudian di tahun ajaran 2017/2018 jumlah siswa baru naik menjadi 65 siswa kemudian di tahun ajaran 2018/2019 jumlah siswa baru menurun menjadi 45 siswa.

Peraturan Pemerintah No. 19 Tahun 2005 pada bab VII pasal 42 ayat 2 mencantumkan bahwa: "Setiap satuan pendidikan wajib memiliki prasarana yang meliputi lahan ruang kelas, ruang pimpinan satuan pendidikan, ruang pendidik, ruang tata usaha, ruang perpustakaan, ruang laboratorium, ruang bengkel kerja, tempat berolahraga, tempat beribadah, tempat bermain, tempat berkreasi dan ruang/tempat lain yang diperlukan untuk menunjang proses pembelajaran yang teratur dan berkelanjutan".

Tabel 2 Data Lingkungan Fisik Pada SMK Cendikia Bangsa

\begin{tabular}{|c|l|c}
\hline No & \multicolumn{1}{|c|}{ Fasilitas } & Keterangan \\
\hline 1 & Ruang Kepala Sekolah & Tersedia \\
\hline 2 & Ruang Guru & Tersedia \\
\hline 3 & Ruang BP/BK & Belum tersedia \\
\hline 4 & Ruang Kantin Sekolah & Tersedia \\
\hline 5 & Ruang Toilet & Tersedia \\
\hline 6 & Ruang Pramuka, Koperasi dan UKS & Belum tersedia \\
\hline 7 & Lapangan Futsal & Tersedia \\
\hline 8 & Lapangan Basket & Belum Tersedia \\
\hline 9 & Ruang Perpustakaan & Tersedia \\
\hline 10 & Ruang Kelas dilengkapi Komputer/Laptop, LCD, infocus dan & Tersedia \\
\hline 11 & LC & Laboratorium Komputer \\
\hline 12 & Musholah & Belum Tersedia \\
\hline 13 & Laboratorium Multimedia & Belum Tersedia \\
\hline 14 & Area Parkir & Tersedia \\
\hline
\end{tabular}

Sumber : SMK Cendikia Bangsa 2020 
Tabel 2 menunjukan lingkungan fisik yang disediakan oleh pihak sekolah belum sepenuhnya mendukung proses pembelajaran. Hal tersebut dikarenakan masih ada lingkungan fisik yang belum tersedia, sehingga menjadi penghambat berlangsungnya proses pembelajaran. Dalam menentukan pilihan lingkungan fisik menjadi pertimbangan orang tua murid. Semakin lengkap lingkungan fisik yang di miliki sekolah, maka orang tua murid akan semakin tertarik dan menjadi prioritas berdasarkan persepsi yang ia peroleh terhadap fasilitas yang tersedia.

Berdasarkan hasil observasi yang penulis lakukan bahwa promosi yang dilakukan pihak sekolah belum optimal sehingga beberapa masyarakat kurang mendapatkan informasi terkait biaya ataupun fasilitas yang ditawarkan oleh sekolah. Serta pemanfaatan teknologi yang belum optimal sehingga promosi belum menjangkau kesemua kalangan masyarakat.

Tabel 3 Kegiatan Promosi Pada SMK Cendikia Bangsa

\begin{tabular}{|c|l|c|c|}
\hline No & \multicolumn{1}{|c|}{ Indikator } & Alat Promosi & Keterangan \\
\hline 1 & Periklanan & Spanduk jalan dan Brosur & Digunakan \\
\hline 2 & Penjualan pribadi & Presentasi di sekolah-sekolah & Tidak digunakan \\
\hline 3 & Promosi penjualan & Potongan Harga/Diskon & Tidak digunakan \\
\hline 4 & Pemasaran Langsung & Even Pameran & Tidak digunakan \\
\hline
\end{tabular}

Sumber : SMK Cendikia Bangsa, 2020

Pada tabel 3 kegiatan promosi yang sudah dilakukan oleh SMK Cendikia Bangsa selama tahun 2020 belumlah dijalankan dengan baik oleh pihak sekolah dari empat kegiatan promosi yang digunakan hanyalah sebatas pada spanduk dan brosur saja.

Penentuan biaya produk jasa yang dilakukan oleh sebuah sekolah sangat berpengaruh dalam keputusan orang tua murid untuk menentukan pilihan pada produk jasa tersebut. Biasanya orang tua murid dalam sekolah akan membanding bandingkan biaya pendidikan, memilih layanan jasa yang biaya pendidikan dasarnya standart dengan penghasilan orang tua murid. Dalam iklim persaingan yang sangat ketat seperti sekarang ini sekolah harus bisa bersaing dalam faktor biaya pendidikan, karena besar kecilnya biaya itu akan bisa mempengaruhi pada keputusan orang tua murid dalam memilih sekolah.

Tabel 4 Perbandingan Biaya SPP

\begin{tabular}{|l|l|c|}
\hline \multicolumn{1}{|c|}{ Nama Sekolah } & \multicolumn{1}{c|}{ SPP Perbulan } & Akreditasi \\
\hline SMK Insan Kamil Tarlita & Rp. 200.000 & B \\
\hline SMKS AL-Anshor Cirarab & Rp. 220.000 & B \\
\hline SMKS Global Insan & Rp. 200.000 & B \\
\hline SMKS Insan Madani Palasari & Rp. 175.000 & B \\
\hline SMKS Penerbangan Dirghantara & Rp. 700.000 & A \\
\hline SMKS PGRI 31 Legok & Rp. 325.000 & A \\
\hline SMKS Yappika Legok & Rp. 250.000 & B \\
\hline SMK Cendikia Bangsa & Rp. 250.000 & B \\
\hline
\end{tabular}

Sumber: Data diolah penulis, 2020 
Berdasarkan pada tabel tersebut dapat diketahui bahwa biaya SPP yang tawarkan SMK Cendikia Bangsa kepada Murid bila dibandingkan dengan sekolah pesaing masih terbilang mahal.

\section{B. KAJIAN LITERATUR}

\section{Lingkungan Fisik}

Menurut Lupiyoadi (2013:120), "Bukti atau lingkungan fisik perusahaan (Physical Evidence) adalah tempat jasa diciptakan, tempat penyediaan jasa dan konsumen berinteraksi, ditambah unsur berwujud apapun yang digunakan untuk mengkomunikasikan atau mendukung jasa tersebut". Kotler \& Amstrong (2014:78) "Physical Evidence adalah bukti yang dimiliki oleh penyedia jasa yang ditujukan kepada konsumen sebagai usulan nilai tambah konsumen".

\section{Promosi}

Cummins (2014:14) mendefinisikan "promosi sebagai serangkaian teknik yang digunakan untuk mencapai sasaran penjualan atau pemasaran dengan menggunakan biaya yang efektif dengan memberikan nilai tambah pada produk atau jasa baik kepada perantara atau pemakai langsung, biasanya tidak dibatasi dalam jangka waktu tertentu".

\section{Harga}

Swastha (2010:30) "Harga merupakan sejumlah uang (ditambah beberapa barang kalau mungkin) yang dibutuhkan untuk mendapatkan sejumlah kombinasi dari barang beserta pelayanannya". Sedangkan Kotler dan Amstrong (2014:430) "harga adalah sejumlah nilai yang konsumen tukarkan untuk jumlah manfaat dengan memiliki atau menggunakan suatu barang atau jasa".

\section{Keputusan Pembelian}

Engel, dkk. (2008:5) mendefinisikan "keputusan pembelian merupakan pemahaman terhadap perilaku konsumen mencakup pemahaman terhadap tindakan yang langsung dilakukan konsumen dalam mendapatkan, mengkonsumsi, dan menghabiskan produk dan jasa, termasuk proses keputusan yang mendahului dan mengikuti tindakan tersebut".

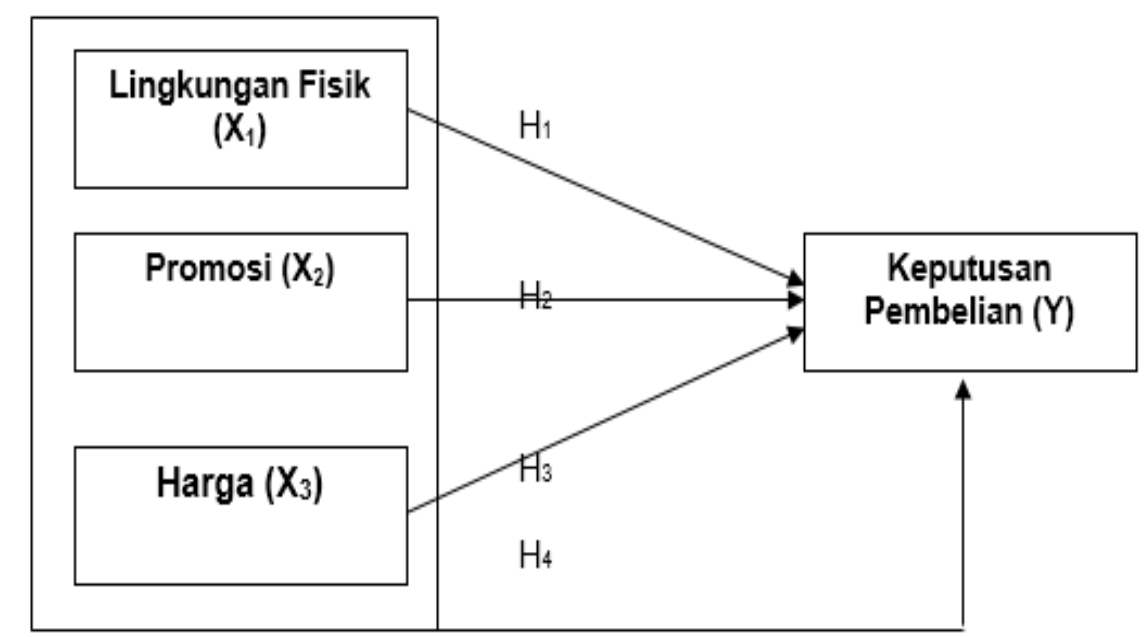

Gambar 1 Model Paradigma Penelitian 


\section{B. METODOLOGI PENELITIAN}

Metode penelitian dengan metodee Asosiatiff, menurut Sugiyono (2015:44) "penelitian Asosiatif bertujuan untuk mengetahui pengaruh atau hubungan antara dua variabel lebih". Populasi adalah seluruh wali murid pada SMK Cendikia Bangsa yang berjumlah 310 wali murid. Teknikk pengambilan sampell mengggunakan "proposional random sampling". Penentu jumlah minimaal sampell dapat dihitung dengaan cara rumus Slovinn sebagai berikut:

$$
\begin{aligned}
& \mathrm{n}=\frac{\mathrm{N}}{1+(\mathrm{N}) \cdot(\mathrm{e})^{2}} \\
& n=\frac{310}{1+(310)(0.05)^{2}} \\
& n=\frac{310}{1,775} \\
& n=174,6 \text { dibulatkan menjadi } 175 \text { wali murid }
\end{aligned}
$$

Dari hasil perhitungan tersebut maka 175 wali murid digunakan sebagai responden. Sementara itu analisiss data menggunakan Regresi Linier Berganda.

\begin{tabular}{|c|c|c|c|c|c|c|}
\hline \multirow{2}{*}{\multicolumn{2}{|c|}{ Model }} & \multicolumn{2}{|c|}{$\begin{array}{l}\text { Unstandardized } \\
\text { Coefficients }\end{array}$} & \multirow{2}{*}{$\begin{array}{c}\begin{array}{c}\text { Standardized } \\
\text { Coefficients }\end{array} \\
\text { Beta } \\
\end{array}$} & \multirow[t]{2}{*}{ t } & \multirow[t]{2}{*}{ Siq. } \\
\hline & & $B$ & Std. Error & & & \\
\hline \multirow[t]{4}{*}{1} & (Constant) & 30,421 & 2,161 & & 14,075 & 0,000 \\
\hline & Lingkungan Fisik & 0,159 & 0,066 & 0,220 & 2,417 & 0,017 \\
\hline & Promosi & 0,247 & 0,063 & 0,361 & 3,938 & 0,000 \\
\hline & Harga & $-0,196$ & 0,033 & $-0,325$ & $-5,857$ & 0,000 \\
\hline
\end{tabular}

\section{HASIL DAN PEMBAHASAN}

\section{Regresi Linier Berganda}

Tabel 5 Regresi Linier Berganda

a. Dependent Variable: Keputusan Wali Murid Sumber: Hasil Olahan Data SPSS 25

$Y=30,421+0,159 X_{1}+0,247 X_{2}-0,196 X_{3}$

1. Konstanta sebesar 30,421 artinya jika seluruh variabel bebas dalam keadaan nol, maka keputusan wali murid akan tetap sebesar 30,421.

2. Nilai regresi $0,159 X_{1}$ menunjukkan semakin baik dan lengkap lingkungan fisik yang ada disekolah maka keputusan wali murid menjadi naik 0,159 .

3. Nilai regresi $0,247 \mathrm{X}_{2}$ menunjukkan semakin gencar promosi yang dilakukan pihak sekolah maka keputusan wali murid menjadi naik 0,247.

4. Nilai regresi $-0,196 \mathrm{X}_{3}$ (negatif) menunjukkan semakin tinggi harga yang ditawarkan pihak sekolah maka keputusan wali murid akan menjadi menurun 0,196. 


\section{Koefisien Determinasi}

Tabel 6 Koefisien Determinasi

\begin{tabular}{|c|c|r|r|r|r|}
\hline Model & $R$ & $\begin{array}{c}\mathrm{R} \\
\text { Square }\end{array}$ & $\begin{array}{c}\text { Adjusted } \mathrm{R} \\
\text { Square }\end{array}$ & $\begin{array}{c}\text { Std. Error of } \\
\text { the Estimate }\end{array}$ & $\begin{array}{c}\text { Durbin- } \\
\text { Watson }\end{array}$ \\
\hline 1 &, $721^{\mathrm{a}}$ & 0,520 & 0,512 & 5,32540 & 1,581 \\
\hline
\end{tabular}

a. Predictors: (Constant), Harga, Lingkungan Fisik, Promosi

b. Dependent Variable: Keputusan Wali Murid Sumber. Hasil Olahan Data SPSS 25

Nilai $R$ Square $=0,520$, menunjukan besarnya pengaruhh variabell lingkungan fisik $\left(X_{1}\right)$, promosii $\left(X_{2}\right)$ dan hargaa $\left(X_{3}\right)$ terhadap variabel keputusn walii muridd $(Y)$ sebesar $52 \%$, adapun $48 \%$ adalah pengaruh dari faktor dari variabel lainnya yang memang tidak diteliti.

\section{Uji t Parsial}

Tabel 7 Uji T Parsial

\begin{tabular}{|c|c|c|c|c|c|}
\hline Variabel & $\begin{array}{c}\text { Prediksi } \\
\text { Arah }\end{array}$ & thituna & $\mathbf{t}_{\text {abel }}$ & Sig & Keputusan \\
\hline $\begin{array}{c}\text { Lingkungan } \\
\text { Fisik }\end{array}$ & $(+)$ & 2,417 & 1,973 & 0,017 & $\begin{array}{c}\text { Positif dan } \\
\text { Signifikan }\end{array}$ \\
\hline Promosi & $(+)$ & 3,398 & 1,973 & 0,000 & $\begin{array}{c}\text { Positif dan } \\
\text { Signifikan }\end{array}$ \\
\hline Harga & $(-)$ & $-5,857$ & 1,973 & 0,000 & $\begin{array}{c}\text { Negatif dan } \\
\text { Signifikan }\end{array}$ \\
\hline
\end{tabular}

Dependent Variable: Keputusan Wali Murid

Sumber. Hasil olahan data SPSS versi 25

1. Berdasarkan hasil pengujian statistik pada tabel 7 angka dari $t_{\text {hitungg }} 2,417>t_{\text {tabell }} 1,973$ dengan angka sig $(0,017<0,05)$ menunjukan diterimanya $\mathrm{H} 1$ dan ditolaknya Ho1 yang berarti bahwa lingkungn fisik memiliki pengaruh positf dan signifikn terhadap keputusan wali murid dalam menentukan pendidikan anak di SMK Cendikia Bangsa.

2. Berdasarkan hasil pengujian statistik pada tabel 7 angka dari $t_{\text {hitungg }} 3,398>t_{\text {tabell }} 1,973$ dengan angka sig $(0,000<0,05)$ menunjukan diterimanya $\mathrm{H} 2$ dan ditolaknya $\mathrm{Ho} 2$ yang berarti bahwa promossi memiliki pengaruh positf dan signifikn terhadap keputusan wali murid dalam menentukan pendidikan anak di SMK Cendikia Bangsa.

3. Berdasarkan hasil pengujian statistik pada tabel 7 angka dari thitungg $-5,857<t_{\text {tabell }} 1,973$ dengan angka sig $(0,000<0,05)$ menunjukan diterimanya $\mathrm{H} 3$ dan ditolaknya Ho3 yang berarti bahwa harga memiliki pengaruh negatif dan signifikn terhadap keputusan wali murid dalam menentukan pendidikan anak di SMK Cendikia Bangsa. 


\section{Uji F Simultan}

Tabel 8 Uji F Simultan

\begin{tabular}{|l|l|r|r|r|r|r|}
\hline \multicolumn{2}{|c|}{ Model } & $\begin{array}{c}\text { Sum of } \\
\text { Squares }\end{array}$ & \multicolumn{1}{c|}{ df } & $\begin{array}{c}\text { Mean } \\
\text { Square }\end{array}$ & F & Sig. \\
\hline \multirow{2}{*}{1} & Regression & 5252,762 & 3 & 1750,921 & 61,739 &, $000^{\circ}$ \\
\cline { 2 - 7 } & Residual & 4849,547 & 171 & 28,360 & & \\
\cline { 2 - 7 } & Total & 10102,309 & 174 & & & \\
\hline
\end{tabular}
a. Dependent Variable: Keputusan Wali Murid
b. Predictors: (Constant), Harga, Lingkungan Fisik, Promosi
Sumber: Hasil Olahan Data SPSS 25

Nilai $F_{\text {hitungg }} 61,739>F_{\text {tabell }} 3,05$ dengan angka sig $(0,000<0,05)$ menunjukan Hipotesis nol ditolak dan Hipotesis alternatif diterima, artinya "secara simultan terdapat pengaruh positif dan signifikan lingkungan fisik, promosi dan harga terhadap keputusan wali murid dalam menentukan pendidikan anak di SMK Cendikia Bangsa".

\section{E. KESIMPULAN}

1. Lingkungan fisik berpengaruh positiff dan signifikaan terhadap keputusan wali murid dalam menentukan pendidikan anak di SMK Cendikia Bangsa ditengok dari hasil pengujiaan hipotesiss ( $t_{\text {hitung }} 2,417>t_{\text {tabel }} 1,973$ ) dan signifikann $(0,017<0,05)$.

2. Promosi berpengaruh positif dan signifikan terhadap keputusan wali murid dalam menentukan pendidikan anak di SMK Cendikia Bangsa ditengok dari hasil pengujiaan hipotesiss (thitung $3,398>t_{\text {tabel }} 1,973$ ) dan signifikann $(0,000<0,05)$.

3. Harga berpengaruh negatif dan signifikaan terhadap keputusan wali murid dalam menentukan pendidikan anak di SMK Cendikia Bangsa ditengok dari hasil pengujiaan hipotesiss (thitung $\left.-5,857<t_{\text {tabel }} 1,973\right)$ dan signifikaan $(0,000<0,05)$.

4. Lingkungan fisik, promosi dan harga berpengaruh positif dan signifikan terhadap keputusan wali murid dalam menentukan pendidikan anak di SMK Cendikia Bangsa dilihat dari hasil pengujian hipotesis diperoleh nilai $\left(F_{\text {hitung }} 61,739>F_{\text {tabel }} 3,05\right)$ dann siginifikan $(0,000<0,05)$.

\section{DAFTAR PUSTAKA}

Cummins, J. (2014), "Sales Promotion", Jakarta: PPM.

Engel, Blackwell, dan Miniar, (2008), “Perilaku Konsumen”. Tangerang: Binarupa Aksara

Kotler, P., \& Gary, A. (2014), “Dasar-Dasar Manajemen Pemasaran”, Jakarta: Erlangga.

Lesmana, R. (2017). Pengaruh Citra Perusahaan Terhadap Keputusan Pembelian Konsumen Pt. Garuda Indonesia Tbk.(Persero). Jimf (Jurnal IImiah Manajemen Forkamma), 1(1).

Rambat, L. (2013), “Manajemen Pemasaran Jasa Berbasis Kompetensi”. (Edisi 3). Jakarta: Salemba Empat.

Sugiyono, (2015), “Metode Penelitian Manajemen”, Bandung: CV Alvabeta.

Swastha \& Irawan, (2015), “Manajemen Pemasaran”. Yogyakarta: BPFE. 